\title{
Overall Optimization Research on Curriculum System and Teaching Contents Oriented with Competence-based Golf Management
}

\author{
Yan $\mathrm{Li}^{1,2}$ \\ ${ }^{1}$ Hebei Institute of Physical Education 050041, \\ ${ }^{2}$ Institute of Physical Education, Hebei Normal University050024 \\ 82 Xuefu Road, Shijiazhuang, Hebei 050041 China \\ Email: 878578182@qq.com
}

\begin{abstract}
The access of Golf to the Olympic Games provides an opportunity for the development of Golf in China, how to distinguish the curriculum setting and contents oriented with Golf management with the directions of other majors and fully reflect the occupation, application and technical characteristics is the important research subject for Golf institutions to cultivate high-quality golf talents. Through combining with the curriculum reform oriented with Golf management of social sports major in Hebei Physical Educational Institute, the research on overall optimization of curriculum system and teaching contents oriented with competence-based golf management is analyzed in this paper.
\end{abstract}

Keywords-competence-based; Golf management direction; curriculum system; teaching content; optimization; research

\section{BACKGROUND}

On October $9^{\text {th }}, 2009$, after the international Olympic committee (IOC) voted in Copenhagen and approved Golf to be entered into the Olympic Games in 2016, it marked that Golf sport which developed in China has returned to sport itself through access to the Olympic Games, and proved that Golf is a healthy, green and popular sport all over the world. Mr. Zhu Dingyao, the executive director of the world's largest Mission Hills Golf Association with 216 holes, said that the access of Golf to the Olympic Games will create a healthy atmosphere for the development of Golf in China. The practitioners in Golf industry should be able to be greatly encouraged in business, which is beneficial to the benign development and progress of Golf industry. Mr. Chu said: "I believe that after Golf enters into the Olympic Games, there will a qualitative leap to recognize Golf in Chinese people, and more and more people will pick up the Golf clubs. The access of Golf to the Olympic Games is undoubtedly a catalyst in this market, and such chemical reaction will be very huge." There are only over 20 years for Golf in China, but so far, there has been 556 Golf courses, 766 driving ranges and more than 400 participants all over the country. The access of Golf to the Olympic Games will promote this sport to be improved and popular in China. In order to increase the level, China has set up a Golf national team and market development system of competition and training as early as 2007, and began to cultivate teenagers, coaches, referees, etc. Generally speaking, the level of Golf in China is still relatively low, and ranked the second-rate in Asia; after access to Olympics, it is a top priority to cultivate the Golf professional talents.

\section{DETERMINE THE PROFESSIONAL OBJECTIVE BASED ON THE OCCUPATIONAL ABILITY}

Occupational ability refers to the required comprehensive ability to engage in the occupational activities, including the professional competence, methodological competence and social competence. Professional competence refers to the required special skills and professional knowledge for engaging in the occupational activities; it is essential to pay attention to mastering the knowledge and skills, so as to obtain the reasonable knowledge-ability structure. Methodological competence refers to the required working method and learning method for engaging in the occupational activities; it is essential to pay attention to learning how to study and work, so as to develop a scientific thinking habit. Social competence refers to the required code of conduct and values for engaging in the occupational activities; it is essential to pay attention to learning how to get along with each other and how to behave, so as to establish a positive attitude towards life. The integration of the aforementioned three elements determines the problem-solving ability for the individual in the dynamic and changing career. According to the regional economic research, our institute determines to cultivate the students majoring in Golf management into the specialized and versatile applied talents who have an all-round development in morality, intelligence, physique and aesthetics, master the elementary theory and technique of Golf, and modern management theory and methods, and the ability to apply the knowledge, and qualify for the junior and mid-level management posts in Golf club and related industry, as well as the work for golf teaching and coaching, event management, industrial development and marketing; so as to cultivate them into the outstanding talents with the potential of professional golfers.

\section{PARTS OF POSTS IN GOLF INDUSTRY AND ANALYSIS OF PROFESSIONAL ABILITY}

\section{A. Analysis on professional ability of Golf coaches}

The job of a Golf coach is to help the club members or golf enthusiasts to learn and improve their skills and improve their performance in a better way.

In addition to teaching in their affiliated club, the coaches also help the manager from caddie department to train the new caddies during the training period, and make the caddies can offer services as quick as possible.

The grades of Golf coaches can be divided into amateur coaches and professional coaches. The former 
refers to the coaches without passing the examination of national professional coaches. Their teaching fees are lower than that of the professional coaches. However, the professional coaches refer to coaches who pass the examination of national coaches. Their teaching method is more systematic and standardized. All their teaching costs are far more than that of the amateur Golf coaches. The professional coaches are also divided into the primary coach, intermediate coach, senior coach, national coach and international coach.

\section{B. Analysis on professional ability of caddie}

Caddies are divided into professional caddie and amateur caddie; there are essential differences between the professional caddie on the service focus, professional degree, role play and the responsibility in the schedule and the amateur caddies on daily service. The Golf training of amateur golf players focuses on physical and mental pleasure, fitness and relaxation. Therefore, whether the player or caddie, their golf experience process places more stress on the mutual trust and responsibility.

Throughout the exercise and games, the caddie can become the right-hand man of the player and the professional adviser in the whole process, understand the terrain, yardage, difficult point in each course and the position of the flagpole every day, and help the professional players to layout the tactics in a better way. Therefore, the caddie shall have the stamina and endurance, physiological anti-pressure ability in face of the events, and proficiency in golf rules, correct interpretation the Golf course information, understanding of the targeted golf, the accurate information transfer and good presentation ability.

Information transfer and good presentation ability is based on: physiological anti-pressure ability in face of the events, the proficiency in golf rules, the accuracy of interpreting the golf course information and the in-depth understanding of the served golf players; only on this premise, the comprehensive ability of professional caddies can be reflected. Only after the caddies have the ability to accurately interpret the competitive ability, athletic habit, athletic psychological change of the professional players, they can guarantee to transfer the information effectively, provide professional and appropriate expression for making professional athletic communications with the players.

\section{CONSTRUCT THE PROFESSIONAL CURRICULUM SYSTEM BASED ON THE PROFESSIONAL ABILITY}

Curriculum system is not only an organic integrity with a set of interrelated and interacted course combination, but also the key link to achieve the training objective of the professional talents. Some Suggestions on All-round Improvement of the Teaching Quality in Higher Vocational Education issued by the Ministry of Education pointed out that "it is essential to reform the curriculum system and teaching contents according to technical field and the job requirements of occupation post (group) and with reference to the related standards of vocational qualification." Professional competence-based curriculum system shall be aimed at the cultivation of students' professional ability, based on the national professional standard, and oriented with the working process of occupation posts, so as to construct a vertically and horizontally intertwined systematic curriculum structure. Therefore, our institute designed the professional-ability curriculum structure with "wide platform and flexible modules" according to the philosophy of getting through to the foundation, professional distribution and characterized cultivation, as shown in Table 1.

TABLE 1: CURRICULUM SYSTEM ORIENTED WITH GOLF MANAGEMENT

\begin{tabular}{|c|c|c|c|c|c|c|c|c|c|c|c|c|c|c|c|}
\hline \multirow{3}{*}{$\begin{array}{l}\text { 过 } \\
\text { D } \\
0 \\
0 \\
0 \\
0 \\
0 \\
0 \\
0\end{array}$} & \multirow{3}{*}{ Course code } & \multirow{3}{*}{ Course title } & \multirow{3}{*}{$\stackrel{\Omega}{\overparen{8}}$} & \multicolumn{3}{|c|}{ Class hour } & \multicolumn{8}{|c|}{ Credit schedule of each academic year and semester } & \multirow{2}{*}{ 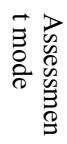 } \\
\hline & & & & \multirow{2}{*}{ 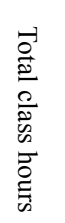 } & \multirow{2}{*}{ 占 } & \multirow{2}{*}{ 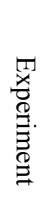 } & \multicolumn{2}{|c|}{$\begin{array}{l}1^{\text {st }} \text { academic } \\
\text { year }\end{array}$} & \multicolumn{2}{|c|}{$\begin{array}{c}2^{\text {nd }} \text { academic } \\
\text { year }\end{array}$} & \multicolumn{2}{|c|}{$\begin{array}{c}3^{\text {rd }} \\
\text { academic } \\
\text { year }\end{array}$} & \multicolumn{2}{|c|}{$\begin{array}{c}4^{\text {th }} \text { academic } \\
\text { year }\end{array}$} & \\
\hline & & & & & & & I & II & III & IV & $\mathrm{V}$ & VI & VII & VIII & \\
\hline \multirow{4}{*}{ 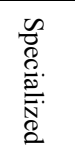 } & & Golf club management & 2 & 36 & & & & & 2 & & & & & & Exam \\
\hline & & Golf events & 2 & 36 & & & & $\mathrm{a} / 2$ & & & & & $\mathrm{a} / 2$ & & Exam \\
\hline & & Golf full-swing skill & 16 & 288 & & & 4 & 4 & 4 & 4 & & & & & Exam \\
\hline & & $\begin{array}{l}\text { Golf course design and } \\
\text { construction }\end{array}$ & 2 & 36 & 36 & & & & 2 & & & & & & Exam \\
\hline \multirow{5}{*}{ 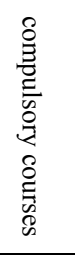 } & & Golf technique tutorials & 2 & 36 & & & & 2 & & & & & & & Exam \\
\hline & & Golf sports equipments & 2 & 36 & 18 & 18 & & & & $\mathrm{a} / 2$ & & & $\mathrm{a} / 2$ & & Exam \\
\hline & & $\begin{array}{l}\begin{array}{l}\text { Foundation of lawn } \\
\text { science }\end{array} \\
\end{array}$ & 2 & 36 & 36 & & & 2 & & & & & & & Exam \\
\hline & & Golf rules & 2 & 36 & & & & 2 & & & & & & & Exam \\
\hline & Sub total & & 30 & 540 & 540 & & & & & & & & & & \\
\hline \multirow{3}{*}{ 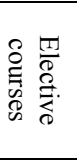 } & & $\begin{array}{l}\text { Professional physical } \\
\text { quality training }\end{array}$ & 8 & 144 & & & 2 & 2 & 2 & 2 & & & & & Exam \\
\hline & & Golf course job training & 4 & 72 & & & & & & 2 & 2 & & & & Exam \\
\hline & & $\begin{array}{l}\text { Lawn planting and care } \\
\text { of Golf course }\end{array}$ & 3 & 54 & 36 & 18 & & & & 2 & & $\mathrm{a} / 2$ & & & Check \\
\hline
\end{tabular}




\begin{tabular}{|c|c|c|c|c|c|c|c|c|c|c|c|c|c|c|c|}
\hline \multirow{18}{*}{ 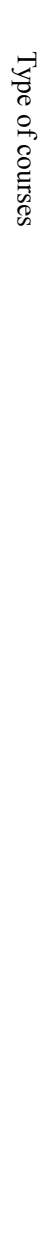 } & \multirow{3}{*}{ Course code } & \multirow{3}{*}{ Course title } & \multirow{3}{*}{$\stackrel{\overbrace{}}{\stackrel{0}{ٍ}}$} & \multicolumn{3}{|c|}{ Class hour } & \multicolumn{8}{|c|}{ Credit schedule of each academic year and semester } & \multirow{3}{*}{ 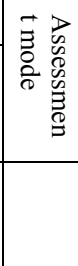 } \\
\hline & & & & \multirow{2}{*}{ 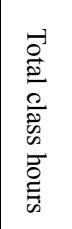 } & \multirow{2}{*}{ 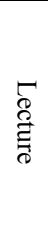 } & \multirow{2}{*}{ 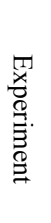 } & \multicolumn{2}{|c|}{$\begin{array}{l}1^{\text {st }} \text { academic } \\
\text { year }\end{array}$} & \multicolumn{2}{|c|}{$\begin{array}{l}2^{\text {nd }} \text { academic } \\
\text { year }\end{array}$} & \multicolumn{2}{|c|}{$\begin{array}{c}3^{\text {rd }} \\
\text { academic } \\
\text { year }\end{array}$} & \multicolumn{2}{|c|}{$\begin{array}{c}4^{\text {th }} \text { academic } \\
\text { year }\end{array}$} & \\
\hline & & & & & & & I & II & III & IV & V & VI & VII & VIII & \\
\hline & & Golf technical practice & 16 & 288 & & & 4 & 4 & 4 & 4 & & & & & Exam \\
\hline & & \begin{tabular}{|l|l|}
$\begin{array}{l}\text { Introduction to Golf } \\
\text { tourism }\end{array}$ \\
\end{tabular} & 1 & 18 & & & & & & & $\mathrm{a} / 2$ & & & & Check \\
\hline & & $\begin{array}{|lr|}\text { Golf } & \text { industrial } \\
\text { management } & \text { and } \\
\text { marketing } & \\
\end{array}$ & 2 & 36 & & & & & & & & 2 & & & Exam \\
\hline & & Golf coach & 2 & 36 & & & & & & & & & 2 & & Check \\
\hline & & Golf referee & 2 & 36 & & & & & & & & 2 & & & Check \\
\hline & & Golf history and culture & 2 & 36 & & & & & 2 & & & & & & Exam \\
\hline & & $\begin{array}{l}\text { Rehabilitation and health } \\
\text { care based on traditional } \\
\text { Chinese medicine }\end{array}$ & 1 & 36 & & & & & & $\mathrm{~b} / 2$ & & & & & \\
\hline & & $\begin{array}{l}\text { Sport event organization } \\
\text { and marketing }\end{array}$ & 2 & 36 & & & & & & & 2 & & & & Check \\
\hline & & $\begin{array}{|lrr|}\begin{array}{l}\text { Business } \\
\text { management } \\
\text { venues }\end{array} & \text { and } \\
\end{array}$ & 2 & 36 & & & & & & & & 2 & & & Check \\
\hline & & \begin{tabular}{|l|} 
Outdoor sports \\
\end{tabular} & 2 & 36 & 6 & 30 & & & & & 2 & & & & Check \\
\hline & & Outward training & 2 & 36 & 6 & 30 & & & & & & 2 & & & Check \\
\hline & & $\begin{array}{|lr|}\text { Fashion } & \text { fitness } \\
\text { programs and } & \text { methods(Aerobic } \\
\text { exercise, step aerobics, } & \text { boxing, Latin } \\
\text { berobics, } \\
\text { yoga, body training, } \\
\text { belly dance, hip-hop, } \\
\text { spinning, finess } \\
\text { equipment projects) } \\
\end{array}$ & 4 & 72 & 6 & 66 & & & & & 2 & 2 & & & Check \\
\hline & & Shuttlecock & 2 & 36 & 6 & 30 & & & & & 2 & & & & Check \\
\hline & & Pearl ball & 2 & 36 & 6 & 30 & & & & & & 2 & & & Check \\
\hline & Sub total & & 57 & 1026 & & & & & & & & & & & \\
\hline
\end{tabular}

\section{V.PRACTICAL TRAINING DESIGN BASED ON CURRICULUM GROUP}

Considering the systematic application, synthesis and improvement of the students' professional theoretical knowledge, in addition to the traditional specialized courses, the specialized practical training based on curriculum group and comprehensive practical training based on specialty are arranged; and the curriculum setting highlights the " $2+2$ " school-running characteristics of the institute, so as to cultivate the high-quality applied talents with solid theoretical foundation and abundant practical experience. The main courses are taught in the $1^{\text {st }}$ and $2^{\text {nd }}$ academic years, the $3^{\text {rd }}$ and $4^{\text {th }}$ academic years are arranged for practical teaching.

\section{CONCLUSION}

The professional theoretical courses based on occupational ability and the special and comprehensive practical training based on occupational skills jointly construct the professional curriculum system oriented with Golf management, and shape the students theoretically and practically, so as to cultivate the students' professional knowledge and train their practical operation ability, and improve the employment competitiveness of the graduates majoring in Golf management.

\section{REFERENCE}

[1] Zhu Weiqiang, Design of standard-based Physical education curriculum. Beijing: Beijing Sport University Press, 2008.

[2] Zhao Jinliang et al. Integration research on teaching program of specialized theoretical courses for athletic training and the corresponding plan $[\mathrm{J}]$. Journal of Shandong Institute of Physical Education 2009. (6)

[3] Gong Wen. Model of higher vocational teaching system based on national vocational standards [J]. Journal of Chinese vocational and technical education, 2009, (26).

[4] Zhu Weiqiang, Pan Haibo. Discussion on the goal of physical education [J]. Journal of Chinese vocational and technical education, 2008.6

Li Yan (1979 - ), Associate professor, doctoral candidates, Research Interests: Sociology of Sport 。

Institute management subject of Hebei Institute of Physical Education, Serial number: 2012JYZHC08 